\title{
Optimasi Konsentrasi Primer dan Suhu Annealing dalam Mendeteksi Gen Leptin pada Sapi Peranakan Ongole (PO) Menggunakan Polymerase Chain Reaction (PCR)
}

\section{Retno Setyawati ${ }^{1}$, Siti Zubaidah ${ }^{2}$}

\begin{abstract}
1Departemen Reproduksi dan Pemuliaan Ternak, Fakultas Peternakan Universitas Gadjah Mada, Yogyakarta, 55281, email: retno.setyawati@ugm.ac.id

2Departemen Nutrisi dan Makanan Ternak Fakultas Peternakan Universitas Gadjah Mada, Yoigyakarta, 55281, email: s zubaidah@ugm.ac.id
\end{abstract}

Submisi: 28 April 2021; Penerimaan: 2 Juli 2021

\begin{abstract}
ABSTRAK
Polymerase Chain Reaction (PCR) adalah suatu teknik sintesis dan amplifikasi DNA secara in vitro. Teknik PCR dapat digunakan untuk mengamplifikasi segmen DNA dalam jumlah jutaan kali hanya dalam beberapa jam. Setiap gen mempunyai primer dengan konsentrasi dan suhu annealing yang berbeda, sehingga perlu dilakukan optimasi konsentrasi primer dan suhu annealing agar didapatkan komposisi dan kondisi PCR yang sesuai sehingga mendapatkan hasil PCR yang optimal. Tujuan penelitian ini adalah untuk mengetahui konsentrasi primer gen Leptin yang menghasilkan produk PCR dengan band yang optimal dan suhu annealing sampel DNA sapi Peranakan Ongole yang menghasilkan produk PCR dengan band yang optimal. Penelitian ini menggunakan sampel darah sapi yang mengandung gen Leptin dengan ukuran produk PCR 467 bp. Penelitian ini sudah dilakukan optimasi variasi penggunaan konsentrasi primer dan suhu annealing. Penelitian ini menggunakan variasi konsentrasi primer $5 \mu \mathrm{M}$ dan $10 \mu \mathrm{M}$ yang berasal dari primer stok $100 \mu \mathrm{M}$, sedangkan suhu annealing $P C R$ yang digunakan yaitu $56^{\circ} \mathrm{C}, 58^{\circ} \mathrm{C}$, $60^{\circ} \mathrm{C}$, dan $62^{\circ} \mathrm{C}$ yang dihitung berdasarkan $(\mathrm{Tm}-5)^{\circ} \mathrm{C}$ dari rata-rata primer forward dan reverse. Produk PCR kemudian di elektroforesis dan dicek hasilnya pada UV transiluminator. Gambar hasil elektroforesis kemudian dibandingkan secara visual. Hasil yang didapat dari penelitian ini yaitu produk PCR gen Leptin yang menghasilkan band yang optimal dihasilkan pada konsentrasi primer $10 \mu \mathrm{M}$ dan suhu annealing $58^{\circ} \mathrm{C}$.
\end{abstract}

Kata Kunci: Gen leptin; konsentrasi primer; suhu annealing; PCR

\section{PENDAHULUAN}

\section{Latar Belakang}

Polymerase Chain Reaction (PCR) adalah suatu teknik sintesis dan amplifikasi DNA (McPherson and Moller, 2006) Teknik PCR dapat digunakan untuk mengamplifikasi segmen DNA dalam jumlah jutaan kali hanya dalam beberapa jam. Sebelum dilakukan PCR dengan sampel penelitian, perlu dilakukan optimasi agar didapatkan komposisi dan kondisi PCR yang sesuai sehingga mendapatkan hasil PCR yang optimal. Seorang teknisi laboratorium dalam mendampingi penelitian atau mengerjakan penelitian dengan PCR seharusnya mengetahui tahapan yang dilakukan jika sampel dan reagen sudah siap untuk dianalisa.

Tulisan ini diharapkan mampu memberikan gambaran kepada teknisi laboratorium ataupun peneliti baru yang akan mengerjakan penelitian amplifikasi DNA sampel darah khususnya darah sapi Peranakan Ongole (PO) menggunakan metode PCR . 
PCR melibatkan tiga tahap siklus temperatur yang berurutan yaitu denaturasi template $\left(94-95^{\circ} \mathrm{C}\right)$, annealing (penempelan) pasangan primer pada untai ganda DNA target (50 $\left.-60^{\circ}\right)$ dan pemanjangan $\left(72^{\circ} \mathrm{C}\right)$. Faktorfaktor yang menentukan keberhasilan PCR diantaranya adalah 1) konsentrasi dan kualitas DNA, 2) temperatur annealing dari kedua primer, 3) konsentrasi $\mathrm{MgCl}_{2}$, 4) enzim polimerase, 5) konsentrasi dan kualitas primer, 6) jumlah siklus PCR, 7) deoksinukleotida triphosphate (dNTP), dan faktor lain seperti larutan buffer (Gelfand and White, 1990).

Pada tahapan optimasi PCR kita dapat membuat variasi tahapan PCR baik waktu, suhu dan komposisi PCR. Pada tulisan ini kami menggunakan contoh optimasi gen Leptin pada DNA Sapi dengan ukuran produk PCR 467bp, dengan variasi konsentrasi primer dan suhu annealing. Suhu annealing yang digunakan dapat dihitung berdasarkan $(\mathrm{Tm}-5)^{\circ} \mathrm{C}$ sampai dengan $(\mathrm{Tm}+5)^{\circ} \mathrm{C}$ (Handoyo dan Rudiretna, 2001). Pada mesin PCR variasi suhu annealing ini dilakukan dengan memasukkan program gradient.

Produk PCR yang dihasilkan kemudian dielektroforesis. Hasil elektroforesis ini dianalisa dengan membandingkan ketebalan band secara visual. Band optimal yang dimaksud adalah band yang tebal, tunggal/single dan sesuai ukuran target (Irmawati, 2003). Konsentrasi primer dan suhu annealing yang menghasilkan band yang optimal inilah yang selanjutnya digunakan untuk PCR pada sampel penelitian.

\section{Tujuan}

Tujuan penelitian ini adalah untuk mengetahui: a) Konsentrasi primer gen Leptin yang menghasilkan produk PCR dengan band yang optimal, b) Suhu annealing sampel DNA sapi Peranakan
Ongole yang menghasilkan produk PCR dengan band yang optimal.

\section{METODOLOGI PENELITIAN}

\section{Alat dan bahan}

Alat yang digunakan adalah mesin PCR Wealtec SEDI-G, erlenmeyer glass

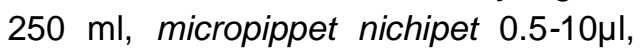
micropipette nichipet 5-50 $\mu \mathrm{l}$, micropippet

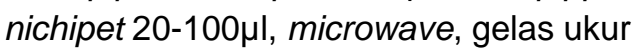
$100 \mathrm{ml}$, plate dan sisir (comb), gloves, gel try, MUPID-2 Mini Gel Electroforesis System (Gambar 4), power supply, parafilm, UV transiluminator UVP TEM40, USA (Gambar 5), gunting, kamera digital, pena marker dan timbangan analitik merk Ohaus PA213.

Bahan yang digunakan adalah sampel DNA sapi Peranakan Ongole, agarose, 1 x TBE Buffer, white tip, yellow tip, microtube $1,5 \mathrm{ml}$, microtube $0,2 \mathrm{ml}$, My $\mathrm{Taq}^{\mathrm{Tm}} \mathrm{HS}$ Red mix.2x, ethidium bromide, loading dye, ladder 100bp, dan double destilated water.

\section{Metode}

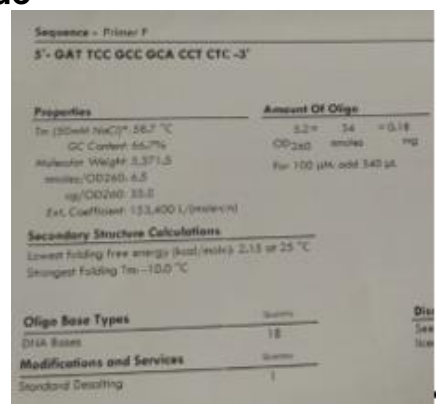

Gambar 1. Datasheet primer Forward gen Leptin

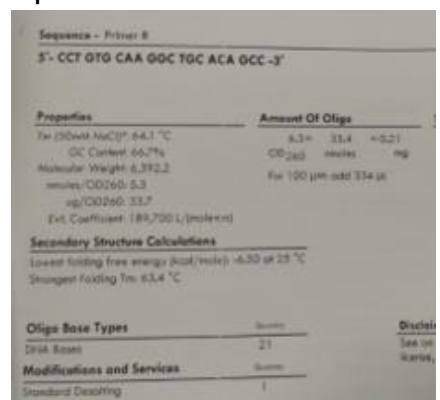

Gambar 2. Datasheet dari primer Reverse gen Leptin 


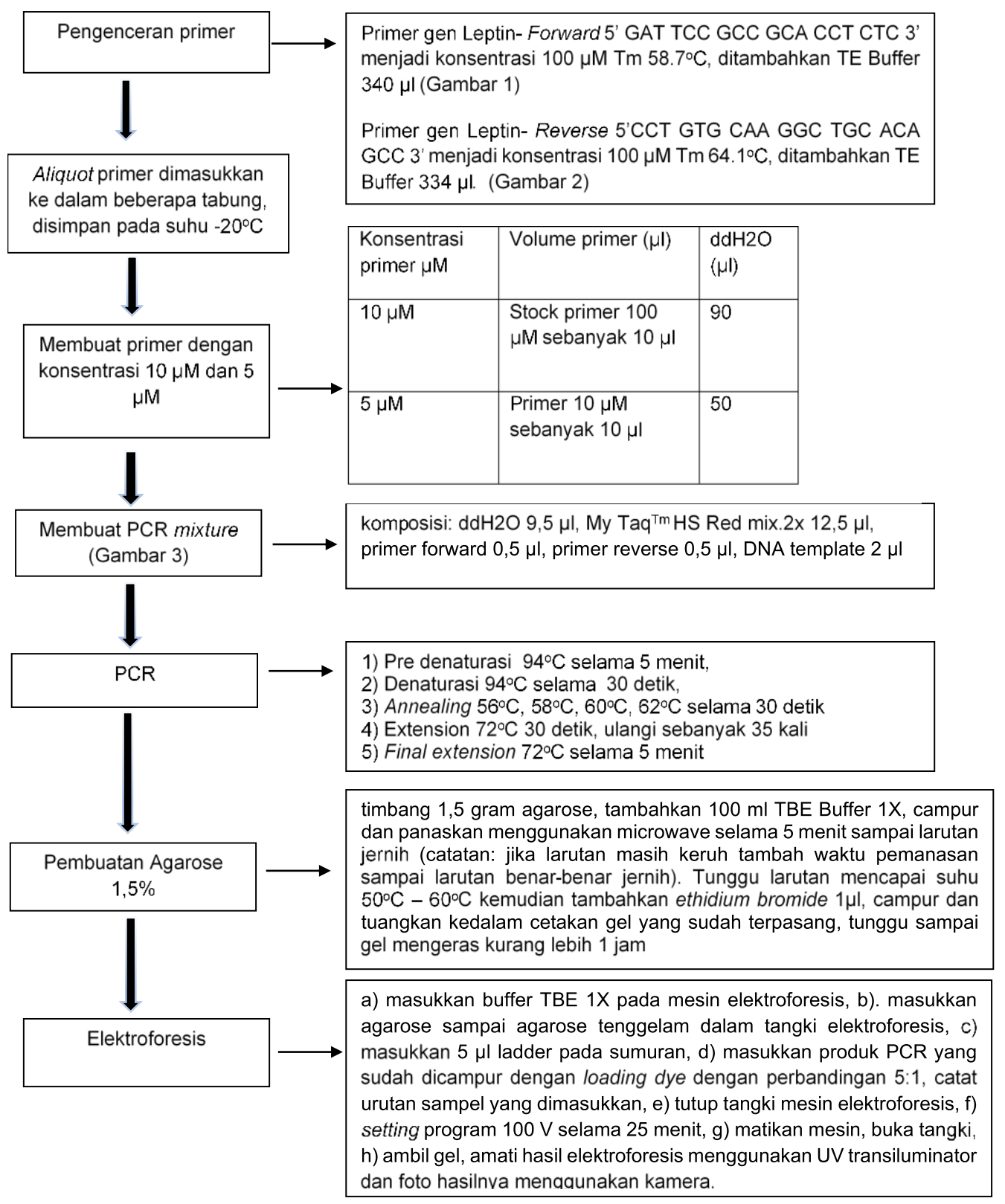

Gambar 3. Diagram alir percobaan

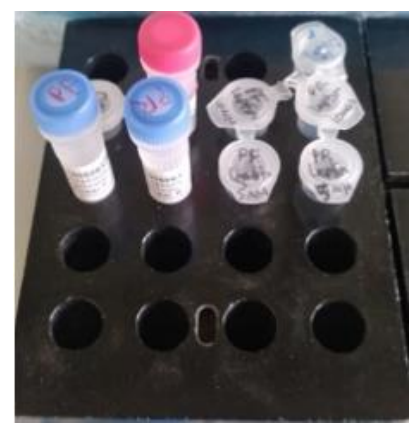

Gambar 4. Reagen dan sampel pada blok es 


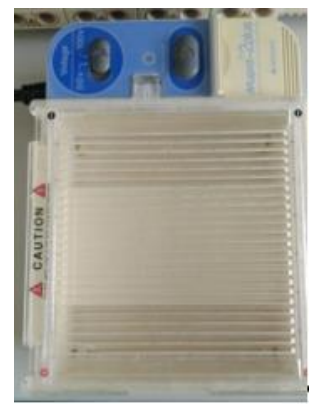

Gambar 5. Mesin elektroforesis

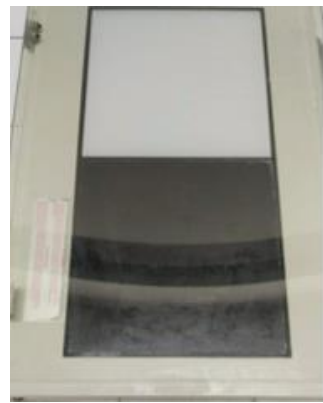

Gambar 6. Alat UV transiluminator

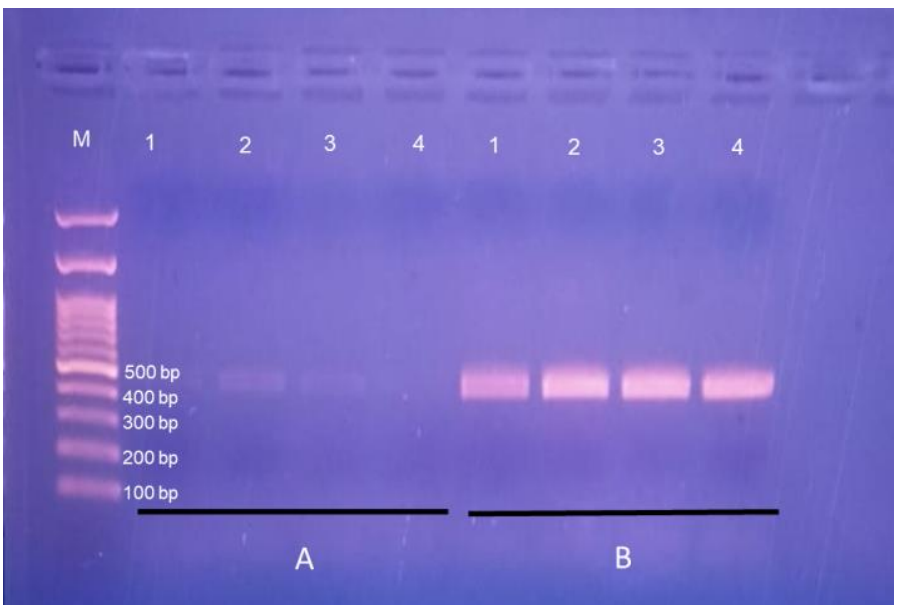

Gambar 7. Hasil elektroforesis sampel PCR gen Leptin pada konsentrasi Primer $5 \mu \mathrm{M}(\mathrm{A})$ $10 \mu \mathrm{M}(\mathrm{B})$ dan variasi suhu annealing $56^{\circ}(1), 58^{\circ} \mathrm{C}(2), 60^{\circ} \mathrm{C}$ (3) dan $62^{\circ} \mathrm{C}(4), \mathrm{M}$ (Marker).

\section{HASIL DAN PEMBAHASAN} Hasil

Pada Gambar 7, kode A merupakan hasil elektroforesis DNA produk PCR dengan konsentrasi primer $5 \mu \mathrm{M}$, dan kode B merupakan hasil elektroforesis DNA produk PCR dengan konsentrasi primer $10 \mu \mathrm{M}$. Angka 1, 2, 3, dan 4 merupakan hasil elektroforesis DNA Produk PCR gen Leptin dengan suhu annealing $56^{\circ} \mathrm{C}, 58^{\circ} \mathrm{C}, 60^{\circ} \mathrm{C}$, dan $62^{\circ} \mathrm{C}$. Hasil elektroforesis DNA gen Leptin didapatkan band 467bp. Produk PCR pada konsentrasi primer $5 \mu \mathrm{M}$ terlihat tipis, sedangkan pada konsentrasi primer $10 \mu \mathrm{M}$ band terlihat tebal, bersih dan sesuai ukuran target yaitu $467 \mathrm{bp}$. Pada suhu annealing $56^{\circ} \mathrm{C}$, $58^{\circ} \mathrm{C}, 60^{\circ} \mathrm{C}, 62^{\circ} \mathrm{C}$ band terlihat tebal, jelas, dan juga ukuran sesuai target, Ladder juga terpisah dengan baik.

\section{Pembahasan}

Pada optimasi ini digunakan produk DNA dengan konsentrasi 0,0278 $\mu \mathrm{g} / \mu \mathrm{l}$ hal ini sesuai dengan pendapat Sambrook et al. (1989) yang menyatakan bahwa konsentrasi DNA sebesar 0,01$0,1 \mu \mathrm{g}$ setiap $\mu \mathrm{l}$ larutan template sudah cukup baik untuk PCR. Band yang tebal, bersih, dan sesuai ukuran target pada hasil elektroforesis merupakan hasil yang optimal. Pada Gambar 7 menunjukkan bahwa pada konsentrasi primer $10 \mu \mathrm{M}$ didapatkan band yang jelas dan sesuai target dibandingkan dengan konsentrasi primer $5 \mu \mathrm{M}$. Konsentrasi primer yang terlalu rendah dan tinggi dapat menyebabkan tidak adanya amplifikasi dan juga bisa menyebabkan pembentukan primer dimer (keadaan dimana band yang terbentuk diikuti oleh 
band lain yang tidak spesifik) (Padmalatha dan Prasad, 2006).

Hasil PCR yang menggunakan suhu annealing $58^{\circ} \mathrm{C}$ menghasilkan band yang paling tebal, lebih terang, jelas dan tunggal/single dibandingkan pada suhu annealing $56^{\circ} \mathrm{C}, \quad 60^{\circ} \mathrm{C}$, dan $62^{\circ} \mathrm{C}$ (Gambar 7). Suhu annealing sangat berpengaruh terhadap proses penempelan primer pada template DNA. Suhu annealing yang terlalu tinggi menyebabkan primer tidak menempel dengan baik pada template hal ini ditandai dengan semakin tipisnya band yang terbentuk, sedangkan suhu annealing yang rendah menyebabkan primer akan menempel pada situs penempelan yang tidak spesifik yang kemudian akan menyebabkan teramplifikasinya fragmen lokus yang tidak diinginkan (Pertiwi et al., 2015). Menurut Irmawati (2003) mengatakan bahwa pita DNA yang tebal dan tunggal/mengumpul (tidak menyebar) menunjukan konsentrasi yang tinggi dan DNA total yang diekstrak dalam kondisi utuh, sedangkan pita DNA yang terlihat menyebar menunjukan adanya ikatan antar molekul DNA yang terputus pada saat proses ekstraksi berlangsung, sehingga genom DNA terpotong menjadi bagian-bagian yang lebih kecil. Terputusnya ikatan antar molekul tersebut dapat disebabkan oleh adanya gerakan fisik yang berlebihan yang dapat terjadi dalam proses pemipetan, pada saat dibolak-balik dalam ependorf, disentrifus, atau bahkan karena temperatur yang terlalu tinggi dan karena aktivitas bahan-bahan kimia tertentu. Tahapan optimasi PCR ini dilakukan untuk setiap gen yang akan di PCR karena kondisi sampel, reagen dan alatalat yang digunakan disetiap laboratorium berbeda-beda.

\section{KESIMPULAN}

Konsentrasi primer yang optimal pada gen Leptin dengan metode PCR adalah $10 \mu \mathrm{M}$ dan suhu annealing adalah $58^{\circ} \mathrm{C}$. Penelitian ini dilakukan untuk memudahkan peneliti dalam melakukan PCR menggunakan sampel darah sapi Peranakan Ongole karena metode PCR merupakan metode yang paling banyak digunakan dalam biologi molekular karena cepat, murah dan sederhana.

\section{DAFTAR PUSTAKA}

Handoyo, D dan Rudiretna, A. 2001. Prinsip Umum dan Pelaksanaan Polymerase Chain Reaction (PCR). Unitas. 9 (1): 17-29.

Irmawati. 2003. Perubahan Keragaman Genetik Ikan Kerapu Tikus Generasi Pertama Pada Stok Hatchery. Thesis. Bogor: IPB

McPherson, M. J and Moller, S. G. 2006. PCR. Second Edition. Published by: Taylor and Francis Group. UK. ISBN 0-203-00267-9.

Padmalatha, K dan Prasad, M.N.V. 2006. Optimization of DNA Isolation dan PCR protocol for RAPD Analisys of Selected Medicinal and aromatic Plant of Conservation Concern from Peninsular India. African Journal of Biotechnology. 5 (3): 230-234.

Pertiwi, N.P.N., Mahardika, I.G.N.K dan Watininiasih, N.L. 2015. Optimasi Amplifikasi DNA Menggunakan Metode PCR (Polymerase Chain Reaction) Pada Ikan Karang Anggota Famili Pseudochromidae (DOTTYBACK) untuk Identifikasi Spesies Secara Molekular. Jurnal Biologi. 19(2): 1-5.

Sambrook, J, Fritsch E.F, and Maniatis,T. 1989. Molekular Cloning: A Laboratory Manual. Cold Spring Harbor Laboratory Press, Cold Spring Harbor, New York, USA. 